\title{
PReS-FINAL-2111: Cytomegalovirus, Epstein Barr virus and Varicella-Zoster virus infections in children with juvenile idiopathic arthritis treated with biologics
}

\author{
V Remy Piccolo*, S Sotou-Bere, A Woerner, R Mouy, B Florkin, B Bader-Meunier, P Quartier \\ From 20th Pediatric Rheumatology European Society (PReS) Congress \\ Ljubljana, Slovenia. 25-29 September 2013
}

\section{Introduction}

Varicella-Zoster (VZV) virus, Cytomegalovirus (CMV) and Epstein Barr virus (EBV) infections may have a severe course in patients on immunosuppressive treatments. Data in Juvenile Idiopathic Arthritis (JIA) patients on biologics are still limited.

\section{Objectives}

To assess the outcome of JIA children with VZV, CMV or EBV infection.

\section{Methods}

We conducted a retrospective analysis of the notes of JIA patients followed between 2006 and 2013 in the French National reference centre for Juvenile Arthritis who developed CMV, EBV or VZV infection while on biologic treatment.

\section{Results}

Ten 3 to 16-year-old children were included for VZV $(\mathrm{n}=8)$, CMV $(\mathrm{n}=2)$ or EBV $(\mathrm{n}=1)$ primoinfection while on etanercept $(n=1)$, adalimumab $(n=2)$, anakinra $(n=2)$ or canakinumab $(n=6)$. Seven patients had concomitant non-steroidal anti-inflammatory (NSAID) treatment, 7 low dose predniso(lo)ne and 4 methotrexate. The 8 patients with VZV infection developed typical skin disease and marked systemic symptoms in some cases, however there was no visceral involvement. Nsaids and steroids were interrupted in all cases. Biologic therapy was interrupted in 7 cases for 5 to 150 days. One patient was treated with acyclovir IV

Paediatric Rheumatology, Hospital Necker, Paris, France and 3 with valacyclovir for 5 to 15 days. The 2 patients who developed primary CMV infection disclosed marked increase of transaminases and moderate increase of gamma glutamyl transferase for 3 weeks; one patient remained asymptomatic and the other one had mild digestive symptoms. Both were on canakinumab and the following injection was postponed. The patient with primary EBV infection developed a rash with fever, hepatomegaly and splenomegaly that resolved after 2 months while NSAID and biologic treatment had been interrupted and corticosteroid treatment prescribed in order to control disease activity. No patient developed macrophage activation syndrome and the 10 patients had a favorable outcome without sequellae.

\section{Conclusion}

In JIA children on biologic, VZV, CMV and EBV infections may result in marked systemic symptoms in some cases, however patients outcome was favorable in this small series while NSAID treatment was systematically stopped, anti-viral therapy prescribed in some VZV infections and biologic therapy continued or only transiently interrupted.

\section{Disclosure of interest}

V. Remy Piccolo: None declared., S. Sotou-Bere: None declared., A. Woerner Grant/Research Support from: Novartis, Consultant for: Chugai-Roche, R. Mouy Grant/Research Support from: Abbvie, Chugai-Roche, Novartis, Pfizer, Consultant for: Abbott-Abbvie, Novartis, Pfizer, Servier, BMS, Sobi, Speakers Bureau: ChugaiRoche, Novartis, Pfizer, B. Florkin: None declared., B. Bader-Meunier Grant/Research Support from: Abbvie, 
Chugai-Roche, Novartis, Pfizer, Consultant for: AbbottAbbvie, Novartis, Pfizer, Servier, BMS, Sobi, Speakers Bureau: Chugai-Roche, Novartis, Pfizer, P. Quartier Grant/Research Support from: Abbvie, Chugai-Roche, Novartis, Pfizer, Consultant for: Abbott-Abbvie, Novartis, Pfizer, Servier, BMS, Sobi, Speakers Bureau: ChugaiRoche, Novartis, Pfizer.

Published: 5 December 2013

doi:10.1186/1546-0096-11-S2-P123

Cite this article as: Remy Piccolo et al:: PReS-FINAL-2111:

Cytomegalovirus, Epstein Barr virus and Varicella-Zoster virus infections in children with juvenile idiopathic arthritis treated with biologics.

Pediatric Rheumatology 2013 11(Suppl 2):P123.

Submit your next manuscript to BioMed Central and take full advantage of:

- Convenient online submission

- Thorough peer review

- No space constraints or color figure charges

- Immediate publication on acceptance

- Inclusion in PubMed, CAS, Scopus and Google Scholar

- Research which is freely available for redistribution

Submit your manuscript at www.biomedcentral.com/submit
C Biomed Central 